the immediate future. Papers on subjects of general interest-permafrost, health problems of Eskimos, Aleuts and Indians, relationship of vegetation to physical environment, sea ice, research and national defence, forestry, fisheries, and mining-were heard on 10 November. Three outstanding films on various aspects of Alaska were shown.

The closing session was held on 11 November. Speeches were made by Robert F. Legget (Canadian National Research Council), Douglas M. Whitaker (U.S. National Research Council), Sam Broadbent (Bureau of the Budget), Ernest L. McCollum (Arctic Aeromedical Laboratory), Jack C. Halderman (Arctic Health Research Center), Ira L. Wiggins (Arctic Research Laboratory), A. L. Washburn (Arctic Institute of North America), Don L. Irwin (Alaska Agriculture Experiment Station), and Terris Moore (University of Alaska).

The following general recommendations were approved:

1. That research information centres be established.

2. That scientific conferences be held from time to time in Alaska.

3. That special committees be established to consider further biological and anthropological research.

4. That the results of scientific investigations be "unclassified" whenever possible and made available for general use.

5. That every effort be made to help publication of results of scientific research.

6. That field research centres be established.

7. That long-term research programmes be encouraged.

Further resolutions recommended full international co-operation in Alaskan research.

The members of the "continuation committee" which is to implement the above recommendations are: John C. Reed (Chairman), Wallace W. Atwood, Jr., Harold J. Coolidge, H. E. Landsberg, and A. L. Washburn.

\title{
GERMAN RAIDERS IN THE ANTARCTIC DURING THE SECOND WORLD WAR
}

TA brief note on this subject was published in the Polar Record, Vol. 4, No. 32, 1946, p. 402-03. The additional information given below has been summarized from "Corsaire à croix gammée contre Royal Navy" by Hans Joachim Brennecke, Constellation. Le monde vu en franf̧ais, Vol. 5, No. 28, 1950, p. 128-49, dealing with the cruise of the Pinguin; and "The cruise of "Schiff 45 " ", by Anthony E. Sukol, United States Naval Institute Proceedings, Vol. 77, No. 5, 1951, p. 476-80, dealing with the Komet. Norwegian accounts of the capture of the whaling fleet were given in Polar-arboken, 1945, p. 89-92 and 93-05.]

German raider " 33 ", the Pinguin (ex-Kandelfels), left Norway in June 1940 disguised as the Soviet Government ship Pechora. The captain, a naval officer named Krüder, was under orders to operate as a commerce raider against British and Allied shipping in the Indian Ocean.

The Pinguin eluded the British blockade by heading well to the north of Iceland, and then steering south-westwards through Denmark Strait, keeping 
as close to the coast of Greenland as the ice would allow. After slipping unchallenged into the open waters of the North Atlantic, the raider changed her disguise, and assumed the appearance of a harmless, rust-stained Greek cargo vessel, the Kassos. The passage south was uneventful, and the Pinguin rounded the Cape of Good Hope and entered the Indian Ocean still disguised as the Kassos.

The raider began her depredations as soon as she had entered the Indian Ocean. After making several "kills", Krüder decided to pass eastwards through the narrow strait between Sumatra and Java into the South Pacific, where there was less likelihood of discovery by the British naval units which he now knew were searching for him. The confined waters of the Dutch East Indies were successfully negotiated, and in October 1940 the Pinguin sailed southwards along the east coast of Australia, and boldly laid mines at the entrance to Sydney harbour.

In November Krüder entered sub-antarctic waters, and cruised westwards through the Southern Ocean, intending to return once more to the waters of the Indian Ocean. Passing south of Iles de Kerguelen and Iles Crozet, the Pinguin headed north, and on 8 December 1940 passed and exchanged greetings with raider " 16 ", the Atlantis, commanded by a German naval officer named Rogge. It is probable that the Atlantis was at this time heading for Kerguelen, where it is known that she had a rendezvous with a supply vessel in January 1941. ${ }^{1}$

Krüder now decided to strike a blow at the Norwegian whaling fleet which was believed to be operating in antarctic waters somewhere south of Bouvetøya. The Pinguin again headed south, passing between Prince Edward Islands and Iles Crozet, and crossed the Antarctic Circle on 16 December. On the following day several icebergs were sighted and-to the great jubilation of the crew-a number of penguins. A Norwegian-speaking wireless operator, named Pastor, the German son of a Norwegian mother, kept a constant watch on the wave-length used by the whaling fleet, and listened attentively to their radio telephone conversations. At this time the Norwegians were operating in approximately lat. $59^{\circ} \mathrm{S}$., long. $2^{\circ} 30^{\prime} \mathrm{W}$. It was discovered that one of the factory ships, the Ole $W$ egger, was expecting to be joined in the near future by the supply vessel Solglimt. Krüder thereforc bided his time, and by means of his direction-finding equipment, plotted the exact position of the Ole Wegger. On 13 January Pastor reported that the Solglimt had moored alongside the Ole Wegger, and that night the Pinguin swiftly closed upon her prey, under cover of a thick mist. As dawn was breaking on 14. January the mist cleared and the Ole Wegger and Solglimt were sighted dead ahead. The Pinguin went hard astern to avoid collision, and Pastor rapidly transmitted a signal in morse code to reassure the Norwegians. No reply was received, and no sign of life could be seen either on the decks of the two vessels, or on the whale-catchers lying alongside. Four boats were lowered

1 H.M.S. Neptune had visited the Prince Edward Islands, Iles Crozet, and Iles de Kerguelen in October 1940, but no signs of enemy activity had been seen. 
and approached the motionless fleet. The boarding parties reached the decks without being challenged, and within a few minutes the wireless transmitters of the Ole Wegger and Solglimt had been seized. The captain of the Ole Wegger, a Norwegian named Normann Andersen, awoke to find himself a prisoner, and his crew, numbering 300, made no attempt to resist. Meanwhile, the Solglimt was also taken without resistance, and the whale-catchers were seized one by one; two, however, which had been early at work and were now returning to the Ole Wegger ignored the Pinguin's signals, and boldly headed away to the west, warning a third catcher to do likewise. Most satisfied with his success Krüder held his fire to avoid useless bloodshed, and made no attempt to pursue. The three catchers made good their escape, and later gave warning to another Norwegian whaling fleet, consisting of the Thorshammer and seven catchers, which made for South Georgia for safety.

Later on 14 January, the Pinguin turned east and made for the second factory ship, the Pelagos, commanded by Fritz Gøthesen. Here, too, the surprise was complete, and there was no attempt to resist the boarding parties. The attendant whale-catchers had already begun the day's work, and the Pinguin stood away while Pastor, using the radio telephone of the Pelagos, ordered the whale-catchers to return to their parent ship. This they did, not without some grumbling, which gave way to amazement when they found themselves confronted by an armed German guard.

Krüder now ordered Küster, the officer he had appointed to take over the Pelagos, to make for Bordeaux. The Ole Wegger, Solglimt, and the eleven remaining whale-catchers were ordered to follow the Pinguin north to a rendezvous called "Andalusien", in the South Atlantic just south of the Equator.

On reaching "Andalusien", the Pinguin fell in with the Duquesa, a British vessel captured earlier by the $A d m i r a l$ Scheer and manned by a German prize crew; on the next day the German supply vessel Alstertor arrived from the north, and in the following days the captured Norwegian whalers came up from the south. The Duquesa was now scuttled, and her crew distributed among the whalers, which were ordered to make singly for Bordeaux. They all reached Bordeaux, with the exception of two catchers which were intercepted by British warships and scuttled by the German guards. The Pinguin, the Alstertor and one of the whalers, renamed the Adjutant, then headed south, making for Kerguelen.

Meanwhile, German raider " 45 ", the Komet, commanded by Konteradmiral R. Eyssen, whose passage along the Northern Sea Route has already been described (in the Polar Record, Vol. 5, Nos. 37/38, 1949, p. 291-95) had been operating in the South Pacific. In January 1941, Eyssen was ordered to enter the Indian Ocean. His chosen route lay far inside the Antarctic Circle, and the Komet sailed due south along long. $180^{\circ}$ towards the Ross Sea. After crossing the Antarctic Circle on 12 February 1941, and reaching her farthest south in lat. $71^{\circ} 36^{\prime} \mathrm{S}$., long. $170^{\circ} 44^{\prime} \mathrm{W}$. the Komet headed westwards north of the coast of the Australian Antarctic Territory. Several Japanese factory ships and catchers were sighted in these waters but no British or Norwegian 
vessels. On 28 February the Komet laid a course for Iles de Kerguelen, and arrived there a week later. An anchorage was found in Port des Iles in Passe Royale, where Eyssen took on board a considerable amount of provisions left at "Royal Sound, Grave Island".1

Several days later, in the second week of March 1941, the Komet sailed to meet the Pinguin and the Alstertor, and the three vessels returned to Kerguelen in company. On this occasion they anchored at Port Couvreux, on the north-west shore of Bras de la Fonderie, where there had once been a French sealing settlement. At this time the Pinguin visited Bassin de la Gazelle, which is entered by a narrow channel at the south-eastern extremity of Bras de la Fonderie. Fresh water was obtained from a small stream which flows into the south-western corner of Bassin de la Gazelle.

During her. stay at Kerguelen, the Pinguin assumed the guise of a Norwegian merchantman, the Tamerlan. The raiders then parted company. ${ }^{2}$ The Pinguin headed northwards towards the coast of India, where Krüder planned to lay more mines. On 7 May 1941, he attacked and sank a British tanker. Most of the crew were picked up by the raider but the wireless operator had had time to transmit distress signals before going down with the ship. The devotion to duty of the wireless operator proved fatal to the raider: early on the following day she was pursued by the British county class cruiser Cornwall. Krüder's hopes that the perfect disguise of the Pinguin would allay suspicions proved futile: the Cornwall's reconnaissance aircraft reported that although in every detail the suspected vessel resembled the Tamerlan, there had been remarkably few members of the ship's company on the bridge when the aircraft flew over, which showed a most unusual reticence on the part of merchant seamen in such remote waters. The cruiser closed and Krüder at last unmasked his guns, hoisted his true colours, and opened fire. The unequal combat lasted less than half-an-hour, and ended with the Pinguin's complete destruction. Krüder, who was not among the few survivors, had fought with great ingenuity and audacity, and had at all times maintained as chivalrous a standard as his profession allowed.

The Pinguin's auxiliary, the Adjutant, escaped the fate of her parent ship, joined the Komet and operated with her for some time in the Indian Ocean. She was finally scuttled in July 1941 when her engines had become too worn to be dependable.

The Komet had meanwhile returned to the Pacific Ocean: in October she rounded Cape Horn and returned to Europe. After a hazardous passage through the English Channel she reached Hamburg safely at the end of

1 Port des Iles, between ile du Cochon, Ile du Chat and Ile du Cimitière, in the western part of Passe Royale, was at one time used by whalers and two huts were erected on Ile du Cochon. These huts are known to have been in ruins in 1929. It is not clear from Sokol's narrative whether the supplies found by Eyssen had been abandoned by the whalers, or, as seems more likely, they had been left there by a German supply vessel.

In November 1941, H.M.A.S. Australia visited Iles de Kerguelen and Iles Crozet, but found no definite evidence of further use of the islands by enemy vessels. Mines were laid by the Australia at four localities in Iles de Kerguelen, including Port des Iles and the entrance to Bassin de la Gazelle. These mines have not yet been removed. 
November 1941. In 516 days she had covered a total distance of 87,000 nautical miles.

The damage done by the two raiders had been considerable. The Komet had sunk nine ships, totalling 57,000 tons gross, and captured one merchantman of 7300 tons. In addition to capturing the whaling fleet, with 22,500 tons of whale oil on board, and sinking by her mines at least two vessels off Sydney, the Pinguin had destroyed a total of 136,550 tons of British and Allied shipping.

J. D. M. BLYTH

\section{THE ANTARCTIC WHALING SEASONS OF 1948-49, 1949-50, AND 1950-51}

A note in the Polar Record, Vol. 5, Nos. 35/36, 1948, p. 222-23 described the antarctic whaling seasons of 1946-47 and 1947-48, although when it was written the catch results of the latter season were not available. Figures for all the post-war pelagic catches up to 1950-51 are now given below in Table 1 .

The antarctic pelagic catches are limited by international agreement to 16,000 Blue Whale units (1 Blue $=2$ Fin $=21$ Humpback $=6$ Sei Whales), but the International Whaling Commission which normally meets once a year is empowered to raise or lower this figure and to modify other regulations. It will be seen from Table 1 that the number of factories (pelagic factory ships) has increased in nearly every season since 1945-46, but in the last three seasons the catch has been stablilized at approximately the requircd limit. In 1945-46 and 1946-47 the limit had not been reached by the end of the open season, which is also fixed by international agreement: from 1947-48 onwards whaling had to be stopped before the end of the season because the limit had been reached. The operation of the limit has been very successful. Weekly catch reports are sent by each factory to the Bureau for Whaling Statistics in Oslo, and when the total is approaching the limit a week's notice is given for all factories to cease whaling. While it is impossible to ensure that the final total will be exactly 16,000 units, the forecasts for the last week's whaling have so far been very accurate and the totals very near 16,000 units.

\section{Table I. Post-war Antarctic pelagic catches}

\begin{tabular}{|c|c|c|c|c|c|c|c|c|c|}
\hline Season & Blue & Fin & $\begin{array}{l}\text { Hump- } \\
\text { back }\end{array}$ & Sei & Sperm & Total & Units & $\begin{array}{c}\text { Fac- } \\
\text { tories }\end{array}$ & $\begin{array}{c}\% \text { Blue } \\
\text { (of } B+F \text { ) }\end{array}$ \\
\hline $1045-46$ & 3526 & 7729 & - & 3 & 216 & 11474 & 7301 & 9 & $31 \cdot 33$ \\
\hline $1946-47$ & 8865 & 12877 & 1 & 2 & 1298 & 23043 & 15303 & 15 & $40 \cdot 77$ \\
\hline $1947-48$ & 6862 & 18999 & 2 & 12 & 2494 & 28360 & 10304 & 17 & $26 \cdot 53$ \\
\hline $1048-49$ & 7399 & 17202 & 13 & 15 & 3692 & 28321 & 15020 & 18 & $30 \cdot 08$ \\
\hline $1949-50$ & 6168 & 18061 & 2117 & 101 & 2570 & 29017 & 16062 & 18 & $25 \cdot 46$ \\
\hline $1950-51$ & 6929 & 17412 & .1625 & 367 & 4739 & 31072 & 16346 & 19 & $28 \cdot 47$ \\
\hline
\end{tabular}

Table 2 shows the number and nationality of the antarctic factories. The factory which operated under the flag of Panama in 1950-51 is the Olympic Challenger. Panama is not at present a party to the International Convention for the Regulation of Whaling.

In addition to the factory ships there are at South Georgia one British, 